\title{
Acute Neonatal Nonketotic Hyperglycinemia: Normal Propionate and Methylmalonate Metabolism
}

\author{
E. REGULA BAUMGARTNER ${ }^{(47)}$ CLAUDE BACHMANN, TONI BRECHBÜHLER, AND HUGO WICK
}

University Children's Hospital, Basel, Switzerland

\section{Extract}

Propionyl-CoA carboxylase and combined methylmalonyl-CoA (MMA-CoA) racemase and -mutase activities were studied in liver and fibroblasts of two patients with the acute neonatal form of nonketotic hyperglycemia. In all experiments, these enzyme activities studied in tissues of the patients were within the range of healthy control subjects, whereas no propionyl-CoA carboxylase activity was measurable in the fibroblasts of a patient with propionic acidemia. Subcellular fractionation of liver and fibroblasts indicated that the normal amounts of MMA-CoA found after incubation of whole tissue homogenate were formed by propionyl-CoA carboxylase, a mitochondrial enzyme, and not by acetyl-CoA carboxylase, which theoretically could also be involved in the carboxylation of propionyl-CoA.

From the above data as well as from clinical and biochemical observations in three patients, it was concluded that there exists a true nonketotic hyperglycinemia which is not related etiologically to the different disorders of the ketotic hyperglycinemia syndrome. True nonketotic hyperglycinemia is not associated with ketoacidosis even after loading with propionate- and MMA precursors. It must be distinguished by exclusion from mild forms of the ketotic hyperglycinemia syndrome which may present clinically as hyperglycinemia without ketosis.

\section{Speculation}

The metabolism of propionate, methylmalonate, and branched chain amino acids is normal in true nonketotic hyperglycinemia. Further investigations will have to show whether the observed block in the glycine cleavage reaction to $\mathrm{CO}_{2}, \mathrm{NH}_{3}$, and a single-carbon tetrahydrofolate derivative represents the primary enzymatic defect. In view of the four enzymatic steps involved in this complex reaction, it may well be that true nonketotic hyperglycinemia also represents a heterogeneous syndrome. The elevated glycine concentrations in the central nervous system (CNS) may play a significant role in the development of the neurologic symptoms.

Hyperglycinemia is found in nonketotic hyperglycinemia and in disorders of propionate, methylmalonate (MMA), and branched chain amino acid intermediate metabolism (ketotic hyperglycinemia syndrome) (29). Mild forms of the ketotic hyperglycinemia syndrome, in which mental retardation and elevated concentrations of glycine are present without episodes of ketoacidosis, may be impossible to distinguish from nonketotic hyperglycinemia on the basis of clinical symptoms alone $(24,27,34)$.

In nonketotic hyperglycinemia a defective oxidation of $\mathrm{C}_{1}$ of glycine to $\mathrm{CO}_{2}$ combined with a defective conversion of $\mathrm{C}_{2}$ of glycine to $\mathrm{C}_{3}$ of serine have been demonstrated in vivo $(2,8)$ and in vitro $(10,33)$. Recently, however, a similar defect has also been found in patients with the ketotic hyperglycinemia syndrome (four patients with propionic acidemia $(1,27,34)$ and one patient with methylmalonic acidemia (33)); i.e., in all five patients a coexistence of defective activity of the glycine cleavage reaction and propionyl-CoA carboxylase or methylmalonyl-CoA mutase, respectively, was demonstrated. In line with these data, Hillman et al. (15) found that isoleucine inhibited the oxidation of glycine to $\mathrm{CO}_{2}$ in fibroblasts of a patient with a $\beta$-ketothiolase deficiency and ketotic hyperglycinemia. These observations suggest that the defect in the glycine cleavage reaction found in nonketotic hyperglycinemia may also represent a secondary phenomenon and not the primary enzymatic defect. It was even proposed that all forms of hyperglycinemia might be associated or even caused by a defect in the metabolism of propionate or branched chain amino acids $(24,31)$.

We have recently observed three nonrelated neonates with a fatal course of nonketotic hyperglycinemia $(5,8,30)$. The severe neurologic symptoms suggesting depression of CNS functions and the absence of ketoacidosis implied that the disease present in these infants was biochemically different from the conditions which may lead to ketotic hyperglycinemia syndrome. This paper presents indirect biochemical evidence for the existence of a true nonketotic hyperglycinemia (37) in which propionate and branched chain amino acid metabolism is normal in vitro and in vivo.

\section{CASE REPORTS}

$D A$ was the patient reported previously by Bachmann et al. (5). No abnormal amounts of short chain fatty acids, other organic acids, their glycine conjugates, or of aldehydes and ketones were detected in her plasma and urine by gas chromatography-mass spectrometry (4).

$M N$ was the second child born to healthy, nonconsanguineous parents by cesarean section at the 39 th week of gestation (30). Hyperglycinemia $(843-1,213 \mu \mathrm{M})$ and hyperglycinuria were first demonstrated on the 2 nd day of life. Metabolic acidosis and ketosis were consistently absent. Excretion of MMA was not elevated. The clinical course was complicated by hyaline membrane disease and concomitant intraventricular hemorrhage. Muscular hypotonia and progressive loss of reflexes were predominant features. The patient died at the age of 5 days in spite of artificial respiration and two exchange transfusions.

The older brother of this child, $M D$ (4 years old), survived acute neonatal manifestations of nonketotic hyperglycinemia but has developed severe mental retardation.

Details for patient $H R$ have been reported previously and a defective glycine cleavage reaction in vivo was demonstrated (8). Oral loading tests with leucine, isoleucine, valine, methionine, and threonine had no clinical effect and caused neither metabolic acidosis nor ketosis. Plasma propionate and urinary MMA were not elevated $(3,6)$.

\section{MATERIALS AND METHODS}

Enzyme assays were performed on liver or fibroblast homogenates and subcellular fractions, respectively.

\section{LIVER PREPARATION}

The livers of patients $D A$ and $M N(38)$ and six control subjects were obtained and frozen at $-18^{\circ}$ within $14 \mathrm{hr}$ after death (Table 2). All subsequent steps were carried out at $0-4^{\circ}$. 
Table 1. Conversion of propionyl-CoA to methylmalonyl-CoA and succinyl-COA by liver homogenate from patient $D A$ and control subjects ${ }^{1}$

\begin{tabular}{|c|c|c|c|c|c|}
\hline \multirow[b]{2}{*}{ Subject } & \multirow[b]{2}{*}{$n$} & \multicolumn{2}{|c|}{$\begin{array}{l}\text { Methyl- } \\
\text { malonate }^{2}\end{array}$} & \multicolumn{2}{|c|}{ Succinate $^{2}$} \\
\hline & & $\bar{\chi}$ & Range & $\bar{\chi}$ & Range \\
\hline Patient DA & 2 & 11.5 & $11-12$ & 55 & $32-78$ \\
\hline \multicolumn{6}{|l|}{ Control subjects } \\
\hline$H T$ & 3 & 173 & $72-272$ & 27 & $6-57$ \\
\hline$S Y$ & 2 & 44 & $42-46$ & 58 & $51-64$ \\
\hline$A S$ & 10 & 21 & $8-36$ & 29 & $38-61$ \\
\hline \multicolumn{6}{|l|}{ Assay controls } \\
\hline$H T$, no propionyl-CoA & 1 & 0 & & 0 & \\
\hline$H T$, boiled liver & 1 & 0 & & 0 & \\
\hline
\end{tabular}

${ }^{1}$ Assay system I: incubation time: $30 \mathrm{~min}$. $n$ : number of assays. For the source of liver specimens see Table 2.

${ }^{2}$ Counts per minute per milligram of protein per $30 \mathrm{~min}$.

Liver Homogenate. Samples from the frozen livers were homogenized in 3 volumes of phosphate-buffered saline (PBS) in a motor-driven Thomas Teflon homogenizer. After 3-5 up and down strokes at $1,400 \mathrm{rpm}$, the homogenate was further disintegrated ultrasonically (150-watt disintegrator (39)) for four 15-sec intervals (samples were allowed to cool for $15 \mathrm{sec}$ between sonication).

Subcellular Fractions. Fresh liver. A mitochondrial preparation made according to the procedure of Hogeboom (16) was isolated from the liver of patient $M N$ and control subject $J R$. The mitochondrial pellet was resuspended in PBS and treated five times by rapid alternating freezing and thawing.

Frozen liver. From patient $D A$ only frozen liver was available. As it was thus impossible to isolate intact mitochondria, a 100,000 $\times g(1 \mathrm{hr})$ sediment was obtained after removal of the nuclear fraction. The resuspended $100,000 \times g$ sediment was frozen and thawed three times and used for the assay. This preparation allowed a clear-cut separation of all particular cell components from the soluble cell extracts.

\section{FIBROBLASTS}

Cell lines were derived from skin biopsies of patient $D A$, eight healthy control individuals (40), and from $C E$, a patient with propionic acidemia $(3,41)$. The skin explants were grown and subcultured in F-10 medium (42) with added $20 \%$ fetal calf serum and antibiotic-antimycotic mixture (43). Fibroblasts used for the assay were obtained after two to eight passages. Monolayers grown to confluence in plastic Falcon flasks $\left(7,500 \mathrm{~mm}^{2}\right)$ were harvested with $0.1 \%$ Versene-trypsin, and washed twice with PBS. The pellet of the intact fibroblasts was resuspended in a small volume of PBS and treated by freezing and thawing five times; this was termed "whole cell extract."

Subcellular Fractions from Fibroblasts of Patient DA and Control Subject $S J$. The pellet of intact, washed fibroblasts $(5-10 \times$ $10^{6}$ cells) was homogenized in buffered $0.25 \mathrm{M}$ sucrose 1:10 with 5 strokes of a Teflon homogenizer. After removing the nuclear fraction, a $100,000 \times g(1 \mathrm{hr})$ sediment was obtained and treated as frozen liver.

\section{ENZYMATIC ASSAY}

Propionyl-CoA carboxylase (EC 6.4.1.3) and combined methylmalonyl-CoA racemase (EC 5.1.99.1) and mutase (EC 5.4.99.2) activity were assayed by a modification of the methods described by Hsia et al. (17) and Flavin and Ochoa (11). Liver or fibroblast preparations were incubated with propionyl-CoA (44) and sodium $\left[{ }^{14} \mathrm{C}\right]$ bicarbonate and the radioactive MMA-CoA and succinyl-CoA formed were measured after hydrolysis of the thioesters.
Assay System I. This was used for the first assays with liver and fibroblasts from patient $D A$ and corresponding control samples. The final volume of $1.0 \mathrm{ml}$ contained (in micromoles): Tris- $\mathrm{HCl}$ buffer (pH 7.4), 200; propionyl-CoA, 0.6; $\mathrm{NaH}^{14} \mathrm{CO}_{3}, 10(5 \mu \mathrm{Ci})$; ATP, 10; $\mathrm{Mg}^{++}, 10 ;$ glutathione (reduced), 10. The reaction was started with $0.4 \mathrm{ml}$ enzyme preparation (liver: $0.5-22 \mathrm{mg}$ protein, fibroblasts: $0.8-9 \mathrm{mg}$ protein).

Assay System $I I$. This was used for patient $M N$, corresponding control subjects, and for all assays with subcellular fractions. The following components differed from assay system I: Tris- $\mathrm{HCl}$ buffer (pH 8.0), $\mathrm{NaH}^{14} \mathrm{CO}_{3}, 20 \mu \mathrm{mol}(5 \mu \mathrm{Ci}) ; \mathrm{KCl}, 200 \mu$ mol. This assay system resulted in at least a fourfold increase of enzyme activity.

After incubation in a metabolic shaker at $30^{\circ}$ for $30-60 \mathrm{~min}$, the reaction was terminated by addition of $0.5 \mathrm{ml} 1 \mathrm{~N} \mathrm{KOH}$. After hydrolysis of the thioesters (room temperatare, $15 \mathrm{~min}$ ), the proteins were precipitated by the addition of $0.5 \mathrm{ml} 5 \mathrm{~N} \mathrm{HCl}$. The mixture was then centrifuged and the supernatant heated in a boiling water bath for $20 \mathrm{~min}$ to remove all ${ }^{14} \mathrm{CO}_{2}$. Fifty microliters of the aqueous phase were removed for counting (= total ${ }^{14} \mathrm{CO}_{2}$ fixation). The remaining supernatant was extracted four times with $15-\mathrm{ml}$ portions of diethyl ether. The combined ether extracts were evaporated to dryness after alcalinization with $0.2 \mathrm{ml} 0.5 \mathrm{~N} \mathrm{KOH}$ in methanol. The residue was dissolved in 1.7 $\mathrm{ml}$ methanol: $0.1 \mathrm{ml}$ was removed for counting ("ether extract") and $1.3 \mathrm{ml}$ were transferred to a 2 -ml test tube and again evaporated to dryness. The residue was taken up in $50 \mu \mathrm{l}$ aqueous solution containing the following unlabeled carriers: MMA, succinic, and 2-ketoglutaric acids. Aliquots of $20 \mu \mathrm{l}$ were subjected to high voltage electrophoresis (HVE): Schleicher Schüll paper, SS $2043 \mathrm{~B}$, in pyridine buffer, pH 3.9 (pyridine-acetate- $\mathrm{H}_{2} \mathrm{O}$ 15:55:930); $25 \mathrm{~min}, 2,200 \mathrm{v}$.

The samples incubated in assay system II were further separated in a second dimension by ascending paper chromatography (2-methyl-1-butanol saturated with $4 \mathrm{~N}$ formic acid for $4 \mathrm{hr}$ ). Additional unlabeled organic acids, mainly Krebs cycle intermediates, were added as reference acids (7).

The reference acids were located by staining the chromatograms with bromphenol blue $(0.04 \%$ in ethanol at $\mathrm{pH} 6.7)$ and afterwards with fast blue $B$ reagent (14). The spots were cut out, placed in vials containing $10 \mathrm{ml}$ of $0.8 \%$ butyl-PBD (45) in methanol-toluol (250:750) and counted in a Packard Tri-Carb liquid scintillation counter.

The recovery of authentic MMA- and succinate when treated by the same procedure was (in percentage; $\bar{\chi} \pm \mathrm{SD}$ ): in ether extract: MMA $(n=19), 84 \pm 12.3$; succinate $(n=19) 80.6 \pm 9.4$; after HVE: MMA $(n=6) 40.3 \pm 12.9$; succinate $(n=8) 60.7 \pm 6.0$. After combined HVE and paper chromatography: MMA $(n=20)$ : $37.9 \pm 7.7:$ succinate $(n=21): 53.4 \pm 11.1$. (23).

Protein was determined according to the method of Lowry et al.

\section{RESULTS}

The activities of propionyl-CoA carboxylase, and of combined MMA-CoA racemase and mutase were estimated by the measurement of the amount of MMA-CoA and succinyl-CoA formed during the assay. The enzyme activities found in homogenates of frozen liver samples markedly decreased with time of storage and frequency of thawing.

Table 1 shows that enzyme assays with liver homogenate from patient $D A$ and three control subjects gave similar activities. The liver samples used for this experiment were matched for storage time and frequency of thawing (Table 2). Similarly, experiments with cultured skin fibroblasts (whole cell extract) from patient $D A$ indicated that enzyme activity was present in the range of seven control individuals (Table 3). In contrast, no MMA-CoA was formed by the fibroblasts of a patient with propionic acidemia $(C E)$

The liver of the second patient, $M N$, and that of control subjects 
Table 2. Source of liver samples ${ }^{1}$

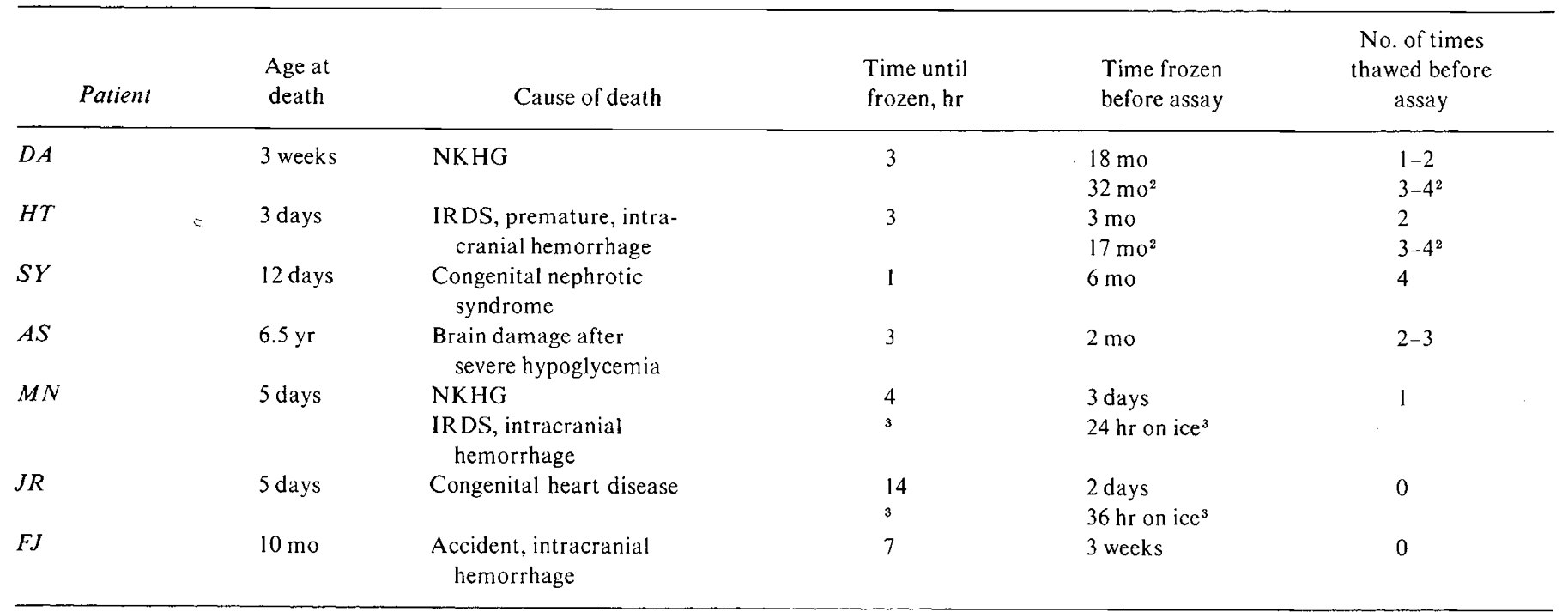

${ }^{1}$ NKHG: nonketotic hyperglycinemia; IRDS: idiopathic respiratory distress syndrome.

${ }^{2}$ Sample used for the preparation of a $100,000 \times g$ sediment.

${ }^{3}$ Sample used for the mitochondrial preparation.

Table 3. Conversion of propionyl-CoA to methylmalonyl (MMA)-CoA and succinyl-CoA by cultured skin fibroblasts: whole cell extract (patient $D A$, control subjects, and a patient, $C E$, with propionic acidemia $)^{1}$

\begin{tabular}{|c|c|c|c|c|c|}
\hline \multirow[b]{2}{*}{ Subject } & \multirow[b]{2}{*}{$n$} & \multirow{2}{*}{$\begin{array}{c}\text { Propionyl- } \\
\text { CoA, } \\
\mathrm{mM} / \text { liter }\end{array}$} & \multicolumn{2}{|c|}{$\begin{array}{c}\text { Methyl- } \\
\text { malonate }+ \\
\text { succinate }^{2}\end{array}$} & \multirow{2}{*}{$\begin{array}{c}\text { Succi- } \\
\text { nate },^{3} \%\end{array}$} \\
\hline & & & $\bar{\chi}$ & Range & \\
\hline Patient DA & 2 & 0.6 & 133 & $130-136$ & $0-30$ \\
\hline Patient DA & 5 & 1.8 & 115 & $64-140$ & $25-50$ \\
\hline \multicolumn{6}{|c|}{ Control subjects } \\
\hline $1,2,3,4$ & 4 & 0.6 & 108 & $86-130$ & $1-6$ \\
\hline $5,6,7$ & 5 & 1.8 & 60 & $45-74$ & $12-20$ \\
\hline Patient $C E^{5}$ & 2 & 0.6 & 0 & & 0 \\
\hline
\end{tabular}

${ }^{1}$ Incubation was carried out for $30 \mathrm{~min}$ in assay system I with $0.9-9 \mathrm{mg}$ fibroblast protein/assay; $n$ : number of assays.

${ }^{2}$ Sum of radioactive MMA and succinate found in counts per minute per milligram of protein per $30 \mathrm{~min}$.

${ }^{3}$ Percentage of the sum of MMA and succinate.

${ }^{4}$ Fibroblasts from healthy control subjects, $1-7$, derived from seven different individuals (40).

${ }^{5} C E$ was a patient with propionic acidemia $(3,41)$.

$J R$ and $F J$ were assayed with assay system II which yielded at least 4 times higher enzyme activity than assay system I. Table 4 shows that a frozen liver sample from patient $M N$ converted propionyl-CoA to MMA-CoA and succinyl-CoA to an extent similar to the livers from the two controls. Addition of glycine $(1.5 \mathrm{mM})$ to the incubation mixture did not inhibit enzyme activity.

It seemed desirable to rule out the possibility that the radioactive MMA-CoA found was formed by acetyl-CoA carboxylase, since it is known that propionyl-CoA is carboxylated not only by propionyl-CoA carboxylase, a mitochondrial enzyme, (18) with a $\mathrm{pH}$ optimum at $\mathrm{pH} 8.0$ (12), but also by acetyl-CoA carboxylase, a soluble enzyme with a pH optimum between pH 6.5 and 7.5 (25, 35). This problem could be solved easily on the basis of the different properties of the two enzymes, as follows.

pH Optimum. Incubation of liver homogenate from patients and control subjects at $\mathrm{pH} 8.0$ resulted in a threefold yield of product as
Table 4. Formation of methylmalonyl-CoA, succinyl-CoA, and other organic acids by liver homogenate obtained from frozen liver of patient $M N$ and control subjects ${ }^{1}$

\begin{tabular}{|c|c|c|c|c|c|c|c|}
\hline \multirow[b]{2}{*}{ Subject } & \multirow[b]{2}{*}{$n$} & \multicolumn{2}{|c|}{$\begin{array}{l}\text { Methyl- } \\
\text { malonate }^{2}\end{array}$} & \multicolumn{2}{|c|}{ Succinate $^{2}$} & \multicolumn{2}{|c|}{$\begin{array}{c}\text { Other } \\
\text { organic } \\
\text { acids }{ }^{3}\end{array}$} \\
\hline & & $\bar{\chi}$ & Range & $\bar{\chi}$ & Range & $\bar{x}$ & Range \\
\hline $\begin{array}{c}\text { Patient } \\
M N \\
\text { Control } \\
\text { subjects }\end{array}$ & 2 & 423 & $327-518$ & 1,783 & $1,754-1,812$ & 234 & $176-293$ \\
\hline$H R$ & 1 & 704 & & 3,487 & & 1,677 & \\
\hline$F J$ & 3 & 2,039 & $848-3,445$ & 1,671 & $1,386-1,876$ & 260 & $200-355$ \\
\hline $\begin{array}{l}\text { Assay con- } \\
\text { trol } \\
M N^{4}\end{array}$ & 1 & 0 & & 4 & & $5^{5}$ & \\
\hline
\end{tabular}

${ }^{1}$ Incubation for $30 \mathrm{~min}$ in assay system II, with 9-19 mg protein/assay. Source of liver sample: see Table $2 . n$ : number of assays.

${ }^{2}$ Counts per minute per milligram of protein per $30 \mathrm{~min}$

${ }^{3}$ Counts mainly found in spots corresponding to intermediates of the citric acid cycle as well as to lactic acid and an unidentified spot.

${ }^{4}$ For the assay control liver homogenate from $M N$ was incubated in assay system II with propionyl-CoA omitted.

${ }^{5}$ Critic, malic and lactic acids.

compared with incubation at $\mathrm{pH}$ 7.4. Even less enzyme activity was found at $\mathrm{pH} 6.5$.

Subcellular Fractionation. Estimation of propionyl-CoA carboxylase activity and MMA metabolism in subcellular liver fractions of patient $M N$ and a matched control sample $(J R)$ indicated that the highest specific activity was associated with the mitochondrial fraction (Table 5). These preparations readily converted propionyl-CoA to MMA-CoA and succinyl-CoA. The latter was further metabolized by the tricarboxylic acid cycle. In two-dimensional pherograms, the spots corresponding to fumaric acid and malic acid regularly gave the highest counts. Less radioactivity was associated with citric, isocitric, cis-aconitic, 2-ketoglutaric and also lactic acids and an unidentified spot.

The results obtained with the subcellular fractions from liver and fibroblasts of patient $D A$ and control subjects are summarized in 
Table 5. Metabolism of propionyl-CoA in subcellular fractions of liver from patient $M N$ and control subject JR ${ }^{1}$

\begin{tabular}{|c|c|c|c|c|c|c|c|c|}
\hline \multirow[b]{2}{*}{ Subject } & \multirow[b]{2}{*}{ Cell fraction } & \multirow[b]{2}{*}{$n$} & \multicolumn{2}{|c|}{ Methylmalonate ${ }^{2}$} & \multicolumn{2}{|c|}{ Succinate $^{2}$} & \multicolumn{2}{|c|}{ Other organic acids ${ }^{3}$} \\
\hline & & & $\bar{\chi}$ & Range & $\bar{\chi}$ & Range & $\bar{\chi}$ & Range \\
\hline \multirow[t]{2}{*}{ Patient $M N$} & Mitochondrial fraction & 3 & 3,336 & $2,247-4,425$. & 6,255 & $5,867-6,642$ & 1,023 & $578-1,461$ \\
\hline & $\begin{array}{l}\text { Supernatant from mitochondrial } \\
\text { fraction }\end{array}$ & 1 & 5,426 & & 79 & & 85 & \\
\hline \multirow[t]{2}{*}{ Control, JR } & Mitochondrial fraction & 2 & 7,449 & $6,938-7,961$ & 8,410 & $8,231-8,590$ & 1,817 & $1,685-1,949$ \\
\hline & $\begin{array}{l}\text { Supernatant from mitochondrial } \\
\text { fraction }\end{array}$ & 1 & 5,616 & & 50 & & 309 & \\
\hline Assay controls & Mitochondrial fraction & 3 & 0 & & 13 & & $37^{5}$ & \\
\hline$(\text { Patient } M N)^{4}$ & $\begin{array}{l}\text { Supernatant from mitochondrial } \\
\text { fraction }\end{array}$ & 4 & 0 & & 0 & & 0 & \\
\hline
\end{tabular}

${ }^{1}$ Incubation for $30 \mathrm{~min}$ in assay system II, with liver kept on ice for $24 \mathrm{hr}(M N)$ and $36 \mathrm{hr}(J R)$ after death. $n$ : number of assays.

${ }^{2}$ Counts per minute per milligram of protein per $30 \mathrm{~min}$.

${ }^{3}$ Counts found in spots corresponding to intermediates of the citric acid cycle and lactic acid and an unidentified spot.

${ }^{4}$ The assay controls were liver fractions from patient $M N$ incubated in complete assay system II with propionyl-CoA omitted.

${ }^{5}$ Fumaric, citric, malic, 2-ketoglutaric acids.

Table 6. Ability of subcellular fractions of liver and fibroblasts to metabolize propionylCoA to methylmalonyl (MMA)-CoA and succinyl-CoA (patient $D A$ and control subjects ${ }^{1}$

\begin{tabular}{|c|c|c|c|c|}
\hline \multirow{2}{*}{$\begin{array}{l}\text { Subject and } \\
\text { source }\end{array}$} & \multirow[b]{2}{*}{ Cell fraction } & \multirow[b]{2}{*}{$n$} & \multicolumn{2}{|c|}{$\begin{array}{c}\text { Methyl- } \\
\text { malonate }+ \\
\text { succinate }^{2}\end{array}$} \\
\hline & & & $\bar{x}$ & Range \\
\hline \multirow[t]{2}{*}{$\begin{array}{l}\text { Patient DA, } \\
\quad \text { liver }\end{array}$} & $\begin{array}{l}100,000 \times g(1 \mathrm{hr}) \\
\text { sediment }\end{array}$ & 1 & 608 & \\
\hline & $\begin{array}{l}\text { Supernatant } \\
\qquad(100,000 \times g)\end{array}$ & 2 & 118 & $109-127$ \\
\hline \multirow[t]{2}{*}{$\begin{array}{c}\text { Control subject, } \\
H T \text {, liver }\end{array}$} & $\begin{array}{l}100,000 \times g(1 \mathrm{hr}) \\
\text { sediment }\end{array}$ & 2 & 472 & n.d. \\
\hline & $\begin{array}{l}\text { Supernatant } \\
\qquad(100,000 \times g)\end{array}$ & 1 & 1,254 & \\
\hline \multirow[t]{2}{*}{$\begin{array}{l}\text { Patient } D A \\
\text { fibroblasts }\end{array}$} & $\begin{array}{l}100,000 \times g(1 \mathrm{hr}) \\
\text { sediment }\end{array}$ & 1 & 659 & \\
\hline & $\begin{array}{l}\text { Supernatant } \\
\qquad(100,000 \times g)\end{array}$ & 2 & 245 & $173-313$ \\
\hline \multirow[t]{2}{*}{$\begin{array}{l}\text { Control subject, } \\
\text { SJ, fibroblasts }\end{array}$} & $\begin{array}{l}100,000 \times g(1 \mathrm{hr}) \\
\text { sediment }\end{array}$ & 3 & 643 & $428-991$ \\
\hline & $\begin{array}{l}\text { Supernatant } \\
\qquad(100,000 \times g)\end{array}$ & 2 & 152 & $127-176$ \\
\hline
\end{tabular}

1 Incubation in assay system II for $60 \mathrm{~min}$. Source of liver sample: see Table 2. $n$ : number of assays; n.d.: Further separation was carried out only in one assay. Assay controls (no propionyl-CoA) were carried out with each experiment and gave consistently no labeled methylmalonate or succinate.

${ }^{2}$ Counts per minute per milligram of protein per $60 \mathrm{~min}$, Sum of MMA + succinate.

Table 6. The high rate of MMA-CoA formation in the $100,000 \times g$ sediments indicates the presence of an intact propionyl-CoA carboxylase in the tissues of $D A$.

The radioactive products formed during the incubation of whole liver homogenate, fibroblast extract, and all subcellular fractions were further analyzed by autoradiography of the two-dimensional pherograms. No additional radioactive spots could be detected in the specimens of the patients as well as in the control subjects. Thus, there was no evidence for an alternate pathway of propionate metabolism in our experiments.

\section{DISCUSSION}

Experiments with crude liver homogenate from both our patients with nonketotic hyperglycinemia $(M N$ and $D A)$ and with whole cell extract of fibroblasts from $D A$ demonstrate a normal conversion of propionyl-CoA to MMA-CoA and succinyl-CoA. Any major contribution of acetyl-CoA carboxylase activity to the formation of MMA-CoA was excluded by experiments done at different $\mathrm{pH}$ levels and with subcellular fractions. We conclude, therefore, that in vitro the enzyme activities of propionyl-CoA carboxylase as well as of MMA-CoA racemase and mutase were normal. Absence of clinical symptoms and of ketoacidosis after loading $H R$ (the third patient) with propionate and MMA precursor amino acids and lack of accumulation of intermediary metabolites in patient $D A$ are evidence that in vivo (l) propionate metabolism is not affected, (2) the metabolism of branched chain amino acids is not grossly abnormal in nonketotic hyperglycinemia.

So far, only a few reports on propionate metabolism in nonketotic hyperglycinemia have been published. Ando et al. (1) found evidence for normal propionate metabolism in the fibroblasts of the index patient $(S F)$ with nonketotic hyperglycinemia by demonstration of normal oxidation of $\left[1-{ }^{14} \mathrm{C}\right]$ propionate to ${ }^{14} \mathrm{CO}_{2}$ Koepp et al. (20) observed no elevation of propionate in their case of nonketotic hyperglycinemia. Both results are in agreement with our findings.

On the other hand, Mahoney et al. (24) discussed propionyl-CoA carboxylase deficiency as a possible cause for nonketotic hyperglycinemia. They reported significant impairment of propionyl-CoA carboxylase activity in the fibroblasts of a 1-year-old hyperglycinemic patient who had never shown clinical attacks of ketoacidosis and, therefore, had been considered to suffer from nonketotic hyperglycinemia. Oral loads of propionyl-CoA precursors, however, led to the classic ketotic syndrome and thus established the diagnosis of propionic acidemia in vivo. A similar clinical course could be anticipated for other mild variants of defects which, in the severe form, are known to lead to the ketotic hyperglycinemia syndrome. In fact, we have recently seen a neonate with methylmalonic acidemia whose disease presented clinically as a mild form of nonketotic hyperglycinemia (6).

The coexistence of a defective activity of propionyl-CoA carboxylase (or MMA-CoA mutase, respectively) and of the glycine cleavage reaction to $\mathrm{CO}_{2}, \mathrm{NH}_{3}$, and a $\mathrm{C}_{1}$ unit has been demonstrated both in vivo and in vitro in some other patients with propionic acidemia and methylmalonic acidemia $(1,27,33)$. Keating et al. (19) described recently a patient in whom a ketotic hyperglycinemia syndrome was associated with a defect in the 
isoleucine degradation pathway (presumably at the $\beta$-ketothiolase site). Glycine oxidation in the cultured fibroblasts of this patient was inhibited by isoleucine (15). The authors concluded that hyperglycinemia seen in the ketotic hyperglycinemia syndrome would appear to be secondary to accumulation of products of isoleucine catabolism. A similar mechanism might also explain propionic acidemia and other metabolic defects leading to the ketotic hyperglycinemia syndrome.

In nonketotic hyperglycinemia, however, a defective glycine cleavage reaction is the only enzymatic defect so far known. In one of our three patients $(H R)$ with the acute neonatal form of nonketotic hyperglycinemia, such a defect has been demonstrated in vivo (8). Defects belonging to the ketotic hyperglycinemia syndrome have been clearly excluded by in vivo and in vitro studies in all three patients presented in this paper. As expected from biochemical studies in vivo, it was found that added glycine did not inhibit either propionate or methylmalonate metabolism in the liver of patients and control subjects. It has been postulated by several investigators that the defective glycine cleavage reaction represents the primary enzymatic defect of this clinically well defined disease $(10,28)$. If this is so, further genetic heterogeneity is to be expected, as four different enzyme systems seem to be involved in this overall reaction $(26,28)$.

Until the enzymatic basis of this disease has been clarified, we suggest that the term "true nonketotic hyperglycinemia" be used to separate it clearly from mild forms of the "ketotic hyperglycinemia syndrome."

The extremely high glycine concentrations found in the CNS of patients with true nonketotic hyperglycinemia in contrast to the only moderate elevations found in ketotic hyperglycinemia $(5,8$, 21) suggest that the defect in glycine metabolism is directly involved in the pathogenesis of true nonketotic hyperglycinemia. Glycine is known to be the major inhibitory transmitter in the brain stem and spinal cord (36). Accordingly, the severe neurologic manifestations of nonketotic hyperglycinemia, which differ markedly from those in ketotic hyperglycinemia, may well be a direct consequence of the glycine accumulation in the CNS.

\section{SUMMARY}

1. Propionyl-CoA carboxylase and MMA-CoA mutase (combined with MMA racemase) activities were studied in liver and fibroblasts of two patients with a lethal neonatal form of nonketotic hyperglycinemia. The enzyme activities in the tissues of the patients were found to be within the range of healthy control subjects.

2. An assay of increased sensitivity was developed to measure propionyl-CoA carboxylase activity.

3. The contribution of acetyl-CoA carboxylase in the formation of the normal amounts of MMA-CoA was excluded by assays at various $\mathrm{pH}$ levels and in different subcellular fractions of liver and fibroblasts.

4. No alternate pathway of propionate in the tissues of the patients could be detected by analysis of the radioactive products formed during the assay.

5. It is concluded that true nonketotic hyperglycinemia is a distinct disease.

\section{REFERENCES AND NOTES}

1. Ando, T., Nyhan, W. L., Connor, J. D., Rasmussen, K., Donnell, G. N., Barnes, N. D., Cottom, D., and Hull, D.: The oxidation of glycine and propionic acid in propionic acidemia with ketotic hyperglycinemia. Pediat. Res., 6: 576 (1972).

2. Ando, T., Nyhan, W. L., Gerritsen, T., Gong, L., Heiner, D. C., and Bray, P. F. Metabolism of glycine in the nonketotic form of hyperglycinemia. Pediat. Res., 2: 254 (1968).

3. Ando, T., Rasmussen, K., Nyhan, W. L., Donnell, G. N., and Barnes, N. D. Propionic acidemia in patients with ketotic hyperglycinemia. J. Pediat., 78 827 (1971).

4. Bachmann, C.: Unpublished data.

5. Bachmann, C., Mihatsch, M. J., Baumgartner, R. E., Brechbühler, T., Bühler,
U. K., Olafsson, A., Ohnacker, H., and Wick, H.: Nicht-ketotische Hyperglyzinaemie: perakuter Verlauf im Neugeborenenalter. Helv. Paediat. Acta, 26: 228 (1971)

6. Baumgartner, E. R.: Unpublished data.

7. Baumgartner, E. R.: A rapid and simple method for the separation of citric acid cycle intermediates and other organic acids (in preparation).

8. Baumgartner, R., Ando., T., and Nyhan, W. L.: Nonketotic hyperglycinemia. J. Pediat., 75: 1022 (1969).

9. Baumgartner, E. R., and Wick, H.: Normal propionate metabolism in "nonketotic hyperglycinemia." New Engl. J. Med., 286: 784 (1972).

10. De Groot, C. J., Troelstra, J. A., and Hommes, F. A.: Nonketotic hyperglycinemia: An in vitro study of the glycine-serine conversion in liver of three patients and the effect of dietary methionine. Pediat. Res., 4: 238 (1970)

11. Flavin, M., and Ochoa, S.: Metabolism of propionic acid in animal tissues. I. Enzymatic conversion of propionate to succinate. J. Biol. Chem., 229: 965 (1957).

12. Giorgio, A. J., and Whitacker, T. R.: Some properties of propionyl-CoA carboxylase partially purified from human liver. Biochem. Med., 7: 473 (1973).

13. Grunert, R. R., and Phillips, P. H.: A modification of the nitroprusside method of analysis for glutathione. Arch. Biochem. Biophys., 30: 217 (1951).

14. Gutteridge, J. M. C., and Wright, E. B.: A simple and rapid thin-layer chromatographic technique for the detection of methyl-malonic acid in urine. Clin. Chim. Acta, 27: 289 (1970).

15. Hillman, R. E., Sowers, L. H., and Cohen, J. L.: Inhibition of glycine oxidation in cultured fibroblasts by isoleucine. Pediat. Res., 7: 945 (1973).

16. Hogeboom, G. H.: Fractionation of cell components of animal tissues. Methods Enzymol., 1: 16, (1955).

17. Hsia, Y. E., Scully, K. J., and Rosenberg, L. E.: Inherited propionyl-CoA carboxylase deficiency in "ketotic hyperglycinemia". J. Clin. Invest., 50: 127 (1971).

18. Kaziro, Y., and Ochoa, S.: The metabolism of propionic acid. Advan. Enzymol., 26: $283(1964)$

19. Keating, J. P., Feigin, R. D., Tennenbaum, S. M., and Hillman, R. E.: Hyperglycinemia with ketosis due to a defect in isoleucine metabolism: A preliminary report. Pediatrics, 50: 890 (1972).

20. Koepp, P., de Groot, C. J., Grüttner, R., and Rybak, F. Ch.: Klinische Befunde und therapeutische Probleme bei der nichtketotischen Hyperglyzinaemie. Monatsschr. Kinderheilk., 121: 401 (1973).

21. Levy, H. L., Nishimura, R. N., Erickson, A. M., and Janowska, S. E.: Hyperglycinemia: In vivo comparison of nonketotic and ketotic (propionic acidemic) forms. I. CSF glycine concentrations and blood/CSF glycine. Pediat. Res., 6: $400(1972)$.

22. Lipmann, F., and Tuttle, L. C.: A specific micromethod for the determination of acyl phosphates. J. Biol. Chem., 159: 21 (1945)

23. Lowry, O. H., Rosebrough, N. J., Farr, A. L., and Randall, R. J.: Protein measurement with the Folin phenol reagent. J. Biol. Chem., 193: 265 (1951).

24. Mahoney, M. J., Hsia, Y. E., and Rosenberg, L. E.: Propionyl-CoA carboxylase deficiency (propionic acidemia): A cause of nonketotic hyperglycinemia, p. 64. Abstracts of the meeting of the Society for Pediatric Research, Atlantic City, New Jersey, April 29-May 1, 1971.

25. Miller, A. L., and Levy, H. R.: Rat mammary acetyl coenzyme A carboxylase. I. Isolation and characterization. J. Biol. Chem., 244: 2334 (1969).

26. Motokawa, Y., and Kikuchi, G.: Glycine metabolism in rat liver mitochondria. V. Intramitochondrial localization of the reversible glycine cleavage system and serine hydroxymethyltransferase. Arch. Biochem. Biophys., 146: 461 (1971).

27. Nishimura, Y., Tada, K., and Arakawa, T.: Coexistence of defective activity in glycine-cleavage reaction and propionyl-CoA carboxylase in the liver of a hyperglycinemic child. Tohoku J. Exp. Med., 113: 267 (1974).

28. Nyhan, W. L.: Nonketotic hyperglycinemia. In : J. B. Stanbury, J. B. Wyngaarden, and D. S. Fredrickson: The Metabolic Basis of Inherited Disease. McGraw-Hill Book Company, New York, 1971.

29. Nyhan, W. L., Ando, T., and Rasmussen, K.: Ketotic hyperglycinemia. In: J. Stern and C. Toothill: Proceedings of the Ninth Symposium of the Society for the Study of Inborn Errors of Metabolism (Churchill Livingston, London, 1972)

30. Prod'hom, L. S.: Personal communication (the two brothers, $M N$ and $M D$, were followed at the University Children's Hospital of Lausanne, Switzerland).

31. Rosenberg, L. E., and Scriver, C. R.: Disorders of amino acid metabolism. In: P. K. Bondy and L. E. Rosenberg: Duncan's Diseases of Metabolism, p. 483 (W. B. Satunders, Philadelphia, 1974).

32. Stadtmann, E. R., and Barker, H. A.: Fatty acid synthesis by enzyme preparations of clostridium kluyveri. VI. Rejaction of acyb phosphates. J. Biol Chem., 184: 769 (1950)

33. Tada, K., Corbeel, L. M., Eeckels, R., and Eggermont, E.: A block in glycine cleavage reaction as a common mechanism in ketotic and nonketotic hyperglycinemia. Pediat. Res., 8: 721 (1974).

34. Tada, K., Narisawa, K., Yoshida, T., Konno, T., Yokoyama, Y., Nakagawa, H., Tanno, K., Mochizuki, K., and Arakawa, T.: Hyperglycinemia: A defect in glycine cleavage reaction. Tohoku J. Exp. Med., 98: 289 (1969)

35. Waite, M., and Wakil, S. J.: Studies on the mechanism of fatty acid synthesis. XI.I. Acetyl-coenzyme A carboxylase. J. Biol. Chem., 237: 2750 (1962).

36. Young, A. B., and Snyder, S. H.: Strychnine binding associated with glycine receptors of the central nervous system. Proc. Nat. Acad. Sci., 70: 2832 (1973)

37. A preliminary report of the results obtained with tissues of one of these patients was published earlier (9). 
38. The liver sample of patient $M N$ was obtained by the courtesy of Professor L. S. Prod'hom.

39. MSE, London, England.

40. The skin biopsies were obtained with the informed consent of the parents of the patient and control subjects. We are grateful to Dr. Erika Buihler for the cultivation of the fibroblasts and to Dr. Uirich Wiesmann, Bern, for providing us with additional control fibroblasts.

41. We wish to thank Dr. W. L. Nyhan for making available fibroblasts of patient $C E$ to us.

42. Difco, Detroit, Mich.

43. Gibco, Grand Island, N.Y.

44. Propionyl-CoA was prepared from propionic anhydride and coenzyme A (11). Its purity was confirmed by ascending chromatography of its hydroxamic acid derivative in water-saturated butanol (32). The concentration of propionyl-CoA was measured by its reaction with hydroxylamine (22) and by titration of the - $\mathrm{SH}$ groups before and after hydrolysis by the nitroprusside method of Grunert and Phillips (13)

45. Ciba-Geigy, Basel, Switzerland.

46. We acknowledge the skillful technical assistance of $\mathrm{L}$. Katajasaari and $\mathrm{N}$. Pollaert.

47. Requests for reprints should be addressed to: E. R. Baumgartner, M.D., University Children's Hospital, Römergasse 8, 4000 Basel, Switzerland.

48. Accepted for publication March 10, 1975.

\title{
Growth and Mineral Metabolism in Very Low Birth Weight Infants. I. Comparison of the Effects of Two Modes of $\mathrm{NaHCO}_{3}$ Treatment of Late Metabolic Acidosis
}

\author{
I. C. RADDE, ${ }^{(34)}$ G. W. CHANCE, K. BAILEY, J. O'BRIEN, G. M. DAY, AND J. SHEEPERS \\ Research Institute, the Hospital for Sick Children, Divisions of Neonatology and Endocrinology; Department of \\ Paediatrics, University of Toronto, Toronto, Canada
}

\section{Extract}

Twenty-six infants weighing less than $1,300 \mathrm{~g}$ at birth were divided into pairs according to birth weight $(900-1,100$ and $1,101-1,300 \mathrm{~g}$ ) and gestational age ("appropriate" (AGA) = mean 31 weeks; and "small" (SGA) = mean 34 weeks). One member of the pairs was then allocated randomly to one of two treatment regimens with oral sodium bicarbonate. Group $A$ was treated whenever base excess was greater than $-8 \mathrm{mEq}$ /liter as detected on twice weekly testing and/or when suspected to be acidotic from failure to gain weight. In group $B$, base excess was maintained within $1 \mathrm{SD}$ of normal $(-3.2 \pm 1.7 \mathrm{mEq} / \mathrm{liter})$. The infants received Enfalac $200 \mathrm{ml} / \mathrm{kg} / 24 \mathrm{hr}$, at $67 \mathrm{cal} / 100 \mathrm{ml}$, with vitamin D 400 IU $/ 24 \mathrm{hr}$ added from age 2 weeks.

The following measurements were made: daily weight, weekly length, skinfold thickness, head circumference, twice weekly blood $\mathrm{pH}, \mathrm{PaCO}_{2}$, base excess, and weekly plasma total calcium, ionic calcium, total magnesium, inorganic phosphorus, and total protein.

There were six pairs each of AGA and SGA infants and two unpaired group $A$ infants. Weekly weight gains did not differ between group $A$ and group $B$ or between AGA and SGA. Length increment was greater in AGA than in SGA babies $(0.94 \pm 0.02$ vs $0.85 \pm 0.04 \mathrm{~cm} /$ week $)$ but not significantly so $(P<0.1)$, and in group $B$ babies compared to group $A$ babies $(0.973 \pm 0.029$ vs 0.83 $\pm 0.037 \mathrm{~cm} /$ week $)(P<0.01)$.

Plasma $\mathrm{pH}$ was lower in group $A(7.23 \pm \mathbf{0 . 0 2})$ than in group $B$ $(7.30 \pm \mathbf{0 . 0 2})$ and calcium ion activity higher (group $A$ 2.72 $\pm \mathbf{0 . 0 4}$; group $B \quad 2.51 \pm 0.06 \mathrm{mEq} /$ liter) between ages 20 and 29 days. Plasma magnesium was higher in group $A(1.77 \pm 0.04 \mathrm{mEq} /$ liter $)$ than in group $B(1.56 \pm 0.06 \mathrm{mEq} /$ liter $)$ from age 20 to 39 days. Inorganic phosphorus concentrations were consistently higher in group $A$ than in group $B$, but the differences did not reach significance. Mean total protein concentrations did not rise above $4.5 \mathrm{~g} / 100 \mathrm{ml}$ and tended to be higher in babies of group $A$ than of group $B$.
Bone age was retarded in all babies. Radiographs available for 7 of 13 SGA infants were normal, whereas 6 of 11 radiographs of AGA babies showed some osteoporotic changes.

\section{Speculation}

Careful control of late metabolic acidosis in infants $<1.3 \mathrm{~kg}$ birth weight results in less ionic hypercalcemia and improved growth in length. In the more immature AGA infants, radiologic osteoporosis was seen. Mineral and protein content of formula currently used for feeding infants of less than $1,300 \mathrm{~g}$ birth weight is inappropriate to their requirements for growth.

Late metabolic acidosis as defined by Kildeberg (12) is common in very low birth weight (VLBW) $(<1.3 \mathrm{~kg})$ infants (22), and the condition may require intermittent correction for several months (18).

Unless corrected, one of the adverse consequences of late metabolic acidosis is said to be failure to gain weight (12). Acidosis may inhibit bone mineralization $(4,14)$, lead to hypercalcemia (ionic fraction), hypercalciuria (23), and may even be associated with reduced rates of skeletal growth (5). These potential complications might be aggravated by routine administration of vitamin $\mathrm{D}$ in doses unrelated to body weight as was recently recommended for the prevention of rickets in these infants (15).

Since the survival rate of VLBW infants is increasing, we consider it important to study the effects of acidosis on their growth and mineral homeostasis. The purpose of this initial study was to compare the influence of two treatment regimens for late metabolic acidosis in infants pair-matched for birth weight and gestational age. We assessed the influence of the regimens on body and skeletal growth and on mineral homeostasis. We hoped to favor bone mineralization by strict maintenance of normal acidbase balance. 